\title{
Islam in the United States of America
}

By Sulayman S. Nyang. Chicago: ABC International Group, Inc., 1999. $165 p p$.

Although Islam is the youngest of the three Abrahamic religions, it has succeeded in making breakthroughs in all comers of the globe. Today, it is the fastest growing religion in the world, and its presence has become a recognized fact in rich industrialized nations like the United States. In the book under review, Professor Sulayman Nyang examines the arrival and development of Islam in America and asserts that it will stand permanently side-by-side with Christianity and Judaism and that these religions will co-exist peacefully.

In the first chapter, the author tells the story of the African Muslim slaves in North America. The discovery of the New World by Columbus resulted in the transplantation of millions of African slaves to work in the plantations of white settler farmers. A large number of slaves were captured in West Africa - a region where Islam had already become firmly rooted. However, the nature of 
slavery itself (as it was practiced in America) and the separation of the children from their Muslim parents impeded the take-off process of Islam in America. These were also critical times for the African Muslim slaves, as they were not allowed to practice their religion freely. This lack of religious tolerance forced many of the slaves to convert to Christianity, which was the faith of their "masters." The author also mentions the wave of Muslim immigrants that occurred during the first quarter of the twentieth century and involved people from the Middle East, North Africa, southern and central Asia, and southern and central Europe. Some of these immigrants returned home after the war, but many decided to stay in the United States in order to pursue the American Dream. The next turning point for Islam was the Islamic Revolution, which broke out in Iran in 1979 and had a very strong impact in the United States due to the country's close alliance with the ousted Shah.

Some of the points mentioned in chapter 1 overlap with issues the author raises in chapter 2, where he talks about the collapse of the Ottoman Empire and the subsequent creation of new states such as Syria, Lebanon, and Jordan. $\mathrm{He}$ also addresses the involvement of Muslims in the building of institutions and organizations to consolidate Islam in America.

In the next chapter, Nyang discusses the professions and occupations of the Muslim immigrants in America. Many of them did not speak English fluently and became merchants, petty traders, and peddlers. Marriage with their American hosts contributed to the spread of Islam in the United States; however, in order to protect the values and principles of Islam in a predominantly Christian environment, the Muslims decided to establish a system that the author calls "inter-group cooperation." This meant, for instance, that social activities such as dancing, drinking, and "dating American style" were not allowed to prevail within the confines of Muslim families.

In chapter 4 , the author says that "Black Africans (though not limited to Muslims) came to the New World before Christopher Columbus." Although there is not enough evidence to substantiate these claims, the original references come from credible scholars such as Ivan van Sertima and Basil Davidson. The author mentions an interesting point when he cites President Lyndon Johnson's immigration reform laws in the 1960s, which subsequently increased the number of Muslim immigrants in the United States. Indeed, in the cold war period, both the United States and the Soviet Union catered to clients from the developing region. When the Soviets opened their doors of higher education to students from developing countries, America, thanks to its enormous wealth, was able to counterbalance the Soviet initiative by offering scholarship programs to Muslim students from poor developing countries. Despite Islam's successful penetration into American society, the Muslims' 
attempts to build new institutions for "greater Islamization" did not gain much momentum during this time. This was due to the existence of various Islamic orientations such as sectarianism and differences of approach (conservative or liberal).

Professor Nyang goes on to identify two major indigenous Muslim communities in the United States. The first community is that of the Elijahian, who are African Americans who follow the teachings of the late Elijah Muhammad who advocated the "rigid separation of races" during his leadership of the Nation of Islam. The second community is the Webbian group that followed the ideas of Alexander Russell Webb, a white American diplomat who converted to Islam when he served in the US Consul in Manila, Philippines, in the early 1980 s, and preached the "colorblind" Islam that should be embraced by all human beings. While some African Americans embraced Islam with a willingness to conform to its orthodox teachings, many perceived the religion "as an ideological weapon in the fight against white racism."

Another significant point the author raises in chapter 6 is the problem of identity that became a major challenge for North American Muslims. Indeed, the African scholar, Ali Mazrui noted in his African Series, "to know who you are is the beginning of wisdom." Since Islam is a way of life, Muslims want to be able to preserve their identity while living in the States and to see their community integrated into the American political sphere. Today, Muslims are part of the mainstream society and even serve in the US military.

In chapter 7, Nyang discusses the role of the Islamic press and in particular the Muslim magazines, newspapers, and refereed journals produced in the United States. Though some works have been discontinued, more and more publications continue to appear. He then gives a statistical analysis of Islamic centers in Canada and the United States: for instance, there are 250 mosques and centers in Canada, and more than 1,000 mosques and centers in the United States.

Despite these impressive figures, Islam continues to receive negative reports from the American print and electronic media. Indeed, many non-Muslim American journalists, intellectuals, and preachers are not inclined to know or understand the true nature of Islam. The situation was further exacerbated when the Iranian Islamic Revolution erupted in 1979 under Ayatollah Khomeini, because it provided the media with tools they could use to brandish negative views of Islam and Islamic fundamentalism. Consequently, the majority of American intellectuals, preachers, journalists, and students do not know the difference between an Islamic state and a Muslim country; they do not know that many Muslim countries are not true Islamic states. The American 
media "confuses Islam with Arab nationalism" and the struggle for freedom with terrorism.

In the final chapter, Nyang speaks about the concept of "televillage" regarding the role of advanced science and technology in bringing human beings closer to each other than ever before. Televillage has indeed reinforced human interdependence that dictates the necessity for Muslims and other religious adherents "to live together and to spend greater time trying to understand one another." In America, Muslims are aware of what their religion permits (halal) and what it forbids (haram). With this in mind, Muslims can co-exist peacefully and harmoniously with People of the Book and atheists alike, without having necessarily to compromise their unequivocal belief in the unseen and life beyond the grave.

Overall, Nyang's book is well written. Its main weakness is that the issues discussed in the chapters sometimes overlap and there is some repetition, which is understandable since the work is based on a collection of essays written for and presented at conferences during the past several years. The strength of the book is its clarity, lucidity, and the powerful messages it conveys to the reader. It is rich in both primary and secondary sources, it is well documented, and it gives an excellent insight into the active role Muslims will continue to play in the building of the American nation. 